\title{
Students' Perceptions of Quality and Satisfaction with Virtual Field Trips of Hotels
}

\author{
Anoop Patiar*, PhD \\ Department of Tourism, Sport and Hotel Management \\ Griffith Business School, Griffith University \\ Emily Ma, PhD \\ Department of Tourism, Sport and Hotel Management \\ Griffith Business School Griffith University \\ Sandra Kensbock, PhD \\ Department of Tourism, Sport and Hotel Management \\ Griffith Business School, Griffith University
}

Russell Cox, M. Hospitality Management

Department of Tourism, Sport and Hotel Management

Griffith Business School, Griffith University

\author{
*Corresponding Author \\ Anoop Patiar \\ Email A.Patiar@Griffith.edu.au \\ Telephone +61 (0)7 37354104 \\ Facsimile +61(0)7 37356743
}

Griffith University Grant for Learning \& Teaching Funded this Project

There is no conflict of interest 


\title{
Students' Perceptions of Quality and Satisfaction with Virtual Field Trips of Hotels
}

\author{
ABSTRACT \\ This paper examines hotel management students' perceptions of the quality aspects of a \\ Virtual Field Trip (VFT) technology based learning and teaching tool, and its effect on their \\ satisfaction. With the help of an online VFT tool, students were familiarized with the \\ theoretical concepts of hotel operations, and then exposed to the insights of the actual \\ operations of two hotels. To assess satisfaction, 182 undergraduate students in a large public \\ university in Australia responded to a self-administered questionnaire. Data was analyzed \\ using descriptive statistics, principle component factor analysis and multiple regression \\ techniques. The results suggest that there are three factors of quality promoting students' \\ satisfaction, however, the factor of 'system quality' was found to be the most important \\ predictor for satisfaction when using the technology based learning and teaching tool. Further \\ analysis revealed that international students' satisfaction with the factor of 'content quality' \\ was higher than domestic students.
}

Keywords: Technology, Quality, Student satisfaction, Learning and teaching, Hotels

\section{Introduction}

The delivery of quality education and assurance of students' satisfaction with learning experiences has become an important factor among educators (Kember \& Ginns, 2012).

Researchers argue that satisfied students are more likely to engage in further education and spread positive word of mouth (Gu, Schweisfurth \& Day, 2010). Monitoring students’ satisfaction and acting on their feedback can promote innovative teaching and learning practice (Arbaugh, 2014; Rienties, Li \& Marsh, 2015). Moreover, education research related to students learning experience offers on opportunity to promote a kind of teaching and 
research nexus that can also improve educators understanding of the learning and teaching phenomena (Baldwin, 2005). For instance, the use of innovative technology based teaching tools in specific courses can promote students reasoning skills and advancing learning through continuous improvements and filling the learning gaps (Winberg \& Hedman, 2008). Busby and Gibson (2010) and other researchers (e.g. Alexander, 2007; Dutton \& Farbrother, 2005) point out that in hospitality education particularly the existence of both theoretical and applied aspects is vital for improving students' learning experiences and maximizing their satisfaction. This is also evident from the hospitality industry perspective, where senior managers prioritize job readiness as the key ingredient for graduates joining the hospitality industry (Phelan \& Mills, 2010; Tews, Stafford \& Tracey, 2011; Wang, Ayres \& Huyton, 2009). The success of hospitality businesses is dependent upon how well its future managers are exposed to real life functioning and operations. Researchers argue that missing the applied aspects in hospitality curricula not only ill prepares graduates but can also result in students’ dissatisfaction and may affect their future career (Busby \& Gibson, 2010; Jenkins \& Walker, 1994).

The rapid growth and expansion of the global tourism and hospitality industry has fueled the demand for hotel management degree programs all over the world. However, due to the high costs of applying practical components and lack of government funding, educational institutions are forced to be cost effective when delivering hospitality education, which has led to large class sizes (Alexander, 2007; Dutton \& Farbrother, 2005). As a result, the presence of practical aspects, such as on campus training laboratories, work integrated experience and inclusion of physical field trips in curriculums, is in decline (Craig-Smith \& Ruhanen, 2006).

To overcome the problem of financial, logistical and time constraints, students may alternatively be exposed to the real work environment through virtual field trips (VFT). These 
have become popular learning and teaching tools among schools and tertiary institutions (e.g., teaching of geosciences, history and engineering), and to some extent started to appear in hospitality and tourism education. A team of hospitality academics and practitioners from an Australian university developed a VFT website and used it in teaching undergraduate hotel management students. The VFT website included interviews with key senior managers of hotels. It also displayed food and beverage operations (e.g., design and layout, still images, videos and reflection of management practices). The course content and the features of the VFT were carefully aligned and all the assessment tasks were designed to promote authentic learning. Moreover, student-centered learning was also promoted as students searched for new knowledge through the VFT, facilitating their own understanding in terms of what they learnt, when they learnt and how they learnt (Hannafin, Hall, \& Hill, 1994). In view of that, this study attempts to fill the gap in the literature by investigating the role of the hotels VFT in strengthening students’ satisfaction levels when embedded in a food and beverage management course, a core within the Bachelor of Hotel Management degree. More specifically, the following three objectives of this study are identified:

1. Examine how many dimensions of quality exist in the VFT of hotels as applied to food and beverage management courses.

2. Recognize which dimension of the VFT is most important in affecting students’ satisfaction as applied to food and beverage management courses.

Due to a large number of international students seeking education in universities in Australia and making significant contribution towards universities funding, it makes them a valuable stakeholder. Hence, it is also important to examine if there are any difference between domestic and international students’ views.

3. Assess if domestic and international students perceptions differ on quality dimensions and satisfaction of VFT of hotels as applied to food and beverage management 
courses.

\section{Literature review}

\subsection{Role of technology in education}

In the twenty first century we are experiencing an increased number of students entering into university education, availability of advanced technology at more affordable prices and faster internet connections, and use of varied delivery modes of education (i.e., face to face, blended and on-line learning) (Sandars, Patel, Goh, Kokatailo \& Lafferty, 2015). Even though it is tempting to embrace the latest technology in teaching hospitality management, the designer of education programs needs to ensure that the essence of the context is not overpowered by the technology. In other words, the use of technology must have specific purposes such as exposing students to the real workings of hotels to provide authentic learning experiences, promote accessibility of information in a flexible manner, and with improved learning outcomes (Wong, Greenhalgh \& Pawson, 2010).

While there is some evidence of technology and education related research, considerable work is needed to better understand the effects of technology on students deep learning rather than surface learning (Wong, et al., 2010). The ultimate goal of technology assisted education is to prepare the future workforce that can effectively solve business problems in a more innovative manner. Indeed, there are several educational theories that can help develop and design enriched learning through an effective blend of technology, and learning and teaching activities. Next a brief discussion of the three key education technology theories is presented.

First, situated cognition theory suggests that effective learning occurs when presented in an appropriate context reflecting the real world and the learner is motivated to take their own responsibility to learn. Certainly, technology can help emulate the real world in the 
teaching environment (Durning \& Artino, 2011). Second, distributive cognition theory suggests that learners exposed to a new situation are asked to solve a problem by applying their existing knowledge and skills. This requires a series of actions such as analysis, comprehension, communication, collaboration, problem solving and making decisions (Honey, Mandinach \& McMillan, 2003). Third, normative theory highlights the significance of education facilitators and the learner's persistent ability to reflect on learning experiences over time to master the intended outcome of learning (Phenix, 1963). Indeed, the use of eportfolio and discussion boards adequately supports this theory.

While the integration of technology is providing humans better control over their life, similarly in the education sphere there is potential to provide university students with authentic, real life experiences and instil high level of competencies. Thus, the above three theories outlined can furnish an environment for effective learning.

\subsection{Hospitality education and international students}

Due to strong emphasis on practical knowledge and skills in hospitality education, the reality of context is extremely important (Busby \& Gibson, 2010). Applied components, such as work integrated learning experience and field visits should be an integral part of hospitality courses (Busby \& Gibson, 2010). However, declining practical facilities, as a result of economic pressures, make it harder to retain these components (King \& Craig-Smith, 2010). Particularly, in Australia over the past decade the government funding to universities has been declining and to cover the short-fall universities aggressively market to international students (McPhee, 2014). As a result, a large number of international students have been seeking education in Australia and contributing to university income (Ruby, 2009). Although international student numbers are increasing and university fees are rising, the aspects of industry experience, work integrated learning and the presence of practical laboratory work 
from the higher education curriculum, specifically in the tourism and hospitality field, has been eliminated to reduce costs. In addition, the increase in class sizes and tighter timetabling makes it more challenging to have field visits to hotels and restaurants as part of learning activities, which further prevents students from gaining valuable insight into live hotel food and beverage operations. However, more recently employability of domestic and international students has reappeared on the Australian government's agenda and universities are encouraged to take positive measures to develop the employability skills of all students, so that they can effectively compete for relevant hospitality management positions in Australia and international job markets (Australian Government, 2015).

It is evident from the research that particularly international students in Australia struggle to secure worthwhile work experience in their chosen discipline. This may be due to cultural differences, poor communication skills and lack of experience and personal contacts (Blackmore, Gribble \& Raimi, 2015), which means they miss out in obtaining valuable initial work experience, and face further difficulty in securing suitable jobs upon graduation (AEI, 2012; Bennet, 2011). Therefore, educators need to build real work practices into the curriculum. This calls for innovative ways of presenting practical components in hospitality education. A VFT offers convenience and active approach which exposes students to realworld learning experiences, enables a richer and more authentic understanding to build upon theoretical knowledge (Smith et al., 2015; Zahra, 2012). Thereby promoting active learning that enables students to engage in realistic tasks providing opportunities for collaboration and deep learning (Colbran et al., 2015; Tigelaar et al., 2004). Furthermore, the application of VFT of hotels food and beverage operations functioning can provide students with a context for assessment in a more authentic manner and help them master some of the key employability skills (e.g., problem solving, team-work, interpersonal skills).

Advances in technology, such as capturing $360^{\circ}$ images, and virtual realities, have 
made VFTs possible. A VFT seems to provide a cost-effective way of merging classroom theory and workplace practice (Franks \& Oliver, 2012). VFTs are designed to promote deeper learning by demonstrating how the theoretical components of hotel operations can be applied in real world settings (Herrington \& Kervin, 2007), and can facilitate active and authentic assessments based on real world scenarios (Herrington \& Herrington, 1998). A VFT can serve as a platform for students to have a "virtual taste” of the industry. Prior to joining the industry in the forms of internships, part-time or full-time jobs, participation in collaborative and creative team work involving critical thinking, problem-solving, decision making and knowledge creation is very important (Glassner \& Eran-Zoran, 2016). A VFT also provides access to top-level leaders and managerial level practices of hospitality organizations in a highly structured manner, which students often could not be exposed to through guest lectures, field trips or even during entry-level internships (Herrington et al., 2002). A VFT has significant implications in blended learning formats (combined online and face to face education), as it offers the flexibility and adaptability needed for groups of parttime, mature and international students, and meets the self-efficacy component of successful blended learning (Shen et al., 2013).

As such, with the advent of technology, a purposely-designed VFT can provide students with practical experience and satisfactorily prepare hotel managers of the future. Research shows that VFTs tend to be more effective in promoting quality education since they comply with the student centered approach; cater for needs of different types of learners; use lecturers' time more efficiently; allow the capture of critical details; and give students flexibility of time and location (Elleven et al., 2006; Patiar, Ma, Kensbock \& Cox, 2016).

\subsection{Students perception of quality and satisfaction with technology}

Quality is considered to be a sign of distinction and fitness for purpose of use, in other words 
having no shortcomings (Juran, 2001), and attempting to undertake on-going improvements by accommodating customers changing needs (Deming, 1985). Whereas Garvin (1988) explains quality based on five keys characteristics (i.e., transcendent-best and top of the range; and product-precise and measurable; user-level of satisfaction; operations-set of specifications; and value based-providing value for money). Wider research shows that quality can help businesses reduce defects, and improve effectiveness and efficiency (Claver, Tari \& Pereira, 2006), as well as satisfy the needs of consumers in dynamic environments (Chako, Davidson \& Green, 2005, Patiar, Wang \& Davidson, 2012). The ultimate aim of any business is to provide a quality product and service, and processes, so that consumers develop a sense of confidence in acquiring it. Equally, the need for quality education cannot be emphasized enough (Kember \& Ginns, 2012).

In a dynamic environment the abstract form of education focusing on principles, theories and processes fails to adequately prepare competent managers for the future (Herrington \& Oliver, 2000). This is because, the abstract form of such education system encourages students to concentrate on rote learning to simply get through the course, rather than accumulating deeper learning to solve business problems using innovative ideas.

Hence, apart from quality learning and teaching programs and courses, higher education is also required to focus on quality systems and processes to enhance graduates teaching and learning experiences and adequately prepare them for their future careers. More specifically, in the context of education, its effectiveness is dependent upon the user's perceptions of competency and the quality of the actual learning and teaching material, and its mode of delivery (Chang \& Tung, 2007; Lin, 2007). According to Pawlowski, (2007) educators need to openly negotiate with their students, and then do all they can to meet their needs. Undeniably, curriculum design and delivery that uses up to date technology, can help achieve and maintain quality. 
Research shows that if users are technologically competent and perceive that the quality of a system is appropriate, then they are more likely to accept and engage with it and develop positive learning experiences (Govindasamy, 2002; Perez-Arostegui, BustinzaSanchez \& Barrales-Molina, 2015). This is particularly the case for the current generation of university students, as they have been born in an era surrounded by technology and feel comfortable with a range of technologies that are already the basis for their information and communication (Oblinger, 2003; Prensky, 2007). Researchers support the application of technology, including a VFT in education as necessary for ensuring students vigorously engage in learning activities (e.g. Palfrey \& Gasser, 2008). Yet, there are other researchers who advocate that the spread of technology (such as a VFT) in education needs further research, as students tend to use technology for leisure purposes rather than for educational purposes (Devine, 2010; Kennedy et al., 2009; Stanton \& Stanton, 2013).

When designing the integration of VFT technologies with courses and curricula, special attention should be applied to how students perceive the use of technologies in education and the roles they play in influencing students' satisfaction and overall learning experiences (Reeves, 2006). Over two decades ago Taylor and Todd (1995) suggested in their Technology Acceptance Model (TAM) that perceived usefulness and perceived ease of use are key factors to ensuring people's acceptance of technology. In the contexts of e-learning, perceived usefulness is the degree to which users believe that a particular system will enhance an individual's performance (Chang \& Tung, 2008). To ensure the usefulness of technologies applied in learning and teaching, materials need to be up to date and relevant to learning contexts and assessment tasks. Educators should focus on the usefulness and the ease of use of an e-learning course website because these characteristics are highly correlated with students’ willingness to use and accept this form of technology (Chang \& Tung, 2008). The technical aspects are also important for students’ overall learning experiences 
(Roca, Chiu \& Martínez, 2006). Researchers generally agree that reliable technical performance, such as ease of use and compatibility, is important for e-learning tools (e.g. Lin \& Chen, 2012; Oh, Ahn \& Kim, 2003). Today’s students are less tolerant with technology failures. Students should feel at ease when using the system and feel the system is free of effort (Chang \& Tung 2008). This importance lies in the fact that the quality of course websites would influence students' acceptance of and engagement with e-learning, and thereby determine the extent of the learning experience and tangible outcomes (i.e., increased knowledge and improved grades) (Morss, 1999).

Moore and Benbasat (1991) suggested that perceived ease of use can offer competitive advantage for an e-learning tool. Ease of use could include easy navigation and short loading times. Compatibility is also important, the degree to which potential users perceive the innovation to be consistent with their values, previous experiences and current needs. Compatibility with multiple browsers and multiple devices are essentially important for today's e-learning tools. Lin and Chen (2012) confirmed compatibility as an important feature for e-learning tools. It is a critical factor for students' behavioral intentions to use the e-learning course websites, along with perceived ease of use and perceived usefulness (Chang \& Tung, 2008). In addition to usefulness and ease of use, innovative features such as visibility and enjoyment are also essential elements for e-learning websites (Chang \& Tung, 2008; Oh et al., 2003). In the context of university education, students are considered to be consumers of education (O’Neill \& Palmer, 2004), and their satisfaction occurs when their expectations are met or exceeded throughout the educational process (Elliott \& Shin, 2002). Abundant evidence in the education literature supports perceived service quality and technological quality, as an antecedent to students’ satisfaction (Gruber et al., 2010; Lo, 2010), and satisfied students are more likely to enhance their retention in the program of study (Bryant, 2006; Helgesen \& Nesset, 2007; Lee, 2002). 
In summary, it seems that perceived usefulness, perceived ease of use and innovative features are essential elements for students’ assessment of e-learning quality. A good quality e-learning system would increase students’ frequency of use, provide knowledge support and would enhance students' satisfaction and overall experiences with learning. For this reason, eventually improve the graduate’s employability skills (Colbran et al., 2015; Tigelaar et al., 2004).

\section{Method}

\subsection{Sample and procedure}

The population of the study included all students enrolled in a second year compulsory food and beverage management course within a Bachelor of Hotel Management degree at an Australian university. At the time of the study, there were 298 students enrolled in the course across two campuses in different cities. Given the fact that VFT is a relatively new tool and in order to understand the perception of students and to further enhance the tool, as a starting point, the study only included the host university that provided seed funding to develop the VFT tool. Inviting all students to participate in the study used a census sampling method. Students participated in the study on voluntary basis according to the university's ethics guidelines. A total 182 completed responses were collected from 298 students, giving a response rate of 61.07 per cent, which were used for the data analysis.

\subsection{Instrument}

The survey technique was used for the data collection. A questionnaire consisting of three parts was adapted from previous studies. Part one was designed to collect students' demographic information. Part two was designed to collect information on students’ perceptions of the performance of each aspect of the VFT using twelve statements adapted 
from previous studies (Chang \& Tung, 2008; Lin, 2007). A panel of four experienced hospitality educators helped to check and modify the wording in order to suit the study context. A five-point Likert-type scale was used where students were asked to rate their level of disagreement or agreement with their perceptions of the quality features of VFT with 1 “strongly disagree” to 5 “strongly agree”. Part three was designed to measure students’ overall perceptions of the VFT and learning experiences with the course (O’Driscoll, 2012). Students responded to an overall question "how satisfied are you with the quality of VFT in enhancing your learning experience in this course” on a five-point Likert scale where 1 equals ‘extremely dissatisfied’ and 5 equals ‘extremely satisfied’. A pilot test with 20 conveniently selected sample was performed and the scale showed a high reliability with a Cronbach’s Alpha of .939.

\subsection{Data analysis}

Using SPSS 22, descriptive statistics (frequency, mean and standard deviation) were performed first in order to gain the general profile of the students. The Mean, Standard Deviation, Skewness and Kurtosis of key variables were also checked for normality before proceeding to further analysis. Principal Component Analysis was performed to identify the underlying dimensions of the VFT website quality, followed by regressions to assess the impact of each factor on students' overall satisfaction with learning experiences. In order to assess the impact of each VFT quality factor on students’ overall satisfaction, a multiple regression was performed. Further, hierarchical regressions were performed to assess if student status (domestic or international) would moderate relationships between quality of the VFT and overall students’ satisfaction.

\section{Findings}




\subsection{Profile of respondents}

The sample included undergraduate students who were enrolled in a Bachelor of Hotel Management at an Australian university. The 298 students taking the food and beverage management course who were exposed to the VFT tool were invited to participate in the study. There were 182 students who completed the survey, representing a response rate of 61.07 per cent. Table 1 summarizes students’ demographic profiles and career related features. 67.3 per cent of participants were female and 36.3 per cent participants were male. The majority of the participants, 84.1 per cent, had no working experience before taking the food and beverage management course, which emphasized the necessity to incorporate insights of hotel food and beverage management (processes and management practices) in the course design. Furthermore, 70.9 per cent of participants were international students and 93.9 per cent of the sample were aged between 18-26. Over 50 per cent of students wanted to work in the hospitality industry after graduation and over 90 per cent of students wanted to achieve at least middle management positions five years after graduation. These aspects clearly demonstrate students take their career planning into consideration during their program of study.

***Please Insert Table 1 Here ${ }^{* * *}$

\subsection{Dimensions of the VFT quality attributes}

To explore the underlying dimensions of the quality attributes of the VFT tool, principle component analysis was performed. The Kaiser-Meyer-Olkin (KMO) measure of sampling adequacy and the Bartlett's Test of Sphericity all passed thresholds. The KMO statistic is a Measure of Sampling Adequacy and values greater than 0.8 can be considered as acceptable (Cerny \& Kaiser, 1977). The KMO value of the data was .916, exceeding the 0.8 threshold 
value. The Bartlett's Test of Sphericity, which is a test to see if samples are from populations with equal variances (Snedecor \& Cochran, 1989), was also significant (Sig. $=.000$ ). The analysis revealed three factors, namely System Quality (SQ), Content Quality (CQ) and Enjoyment Quality (EQ), explaining 73.431 per cent with all 12 items. Factor 1 SQ contained four attributes which covered ease of access, ease of navigate, loading time and effectiveness of the VFT. Factor 2 CQ contained five attributes which mainly covered learning material quality and Factor 3 EQ contained three attributes covering the attractiveness and fun aspects of the VFT (Table 2 displays factor analysis results).

***Please Insert Table 2 Here***

\subsection{Determinants of students' satisfaction}

In order to establish if the three dimensions of the VFT significantly related to students' overall satisfaction, a multiple regression was performed using the three dimensions as independent variables (IV) and students' overall satisfaction as the dependent variable (DV). Specifically,

$$
\text { Satisfaction }^{\prime}=\mathrm{a}+\mathrm{b}_{1} \mathrm{SQ}_{1}+\mathrm{b}_{2} \mathrm{CQ}+\mathrm{b}_{3} \mathrm{EQ}
$$

The regression equation is,

$$
\text { Satisfaction' }^{\prime}=4.059+.336 \mathrm{SQ}+.215 \mathrm{CQ}+.260 \mathrm{EQ}
$$

The result of the regression showed that all three dimensions, namely system quality, enjoyment quality and content quality, were significant predictors for students’ overall satisfaction. However, system quality was found to be the most important factor in achieving student satisfaction with the VFT. The regression results are summarized in Table 3.

$$
\text { ***Please Insert Table } 3 \text { Here*** }
$$

\subsection{Moderating effects}


In order to assess if relationships between VFT aspects and students' overall satisfaction differ between domestic and international students, hierarchical regressions were performed, following three steps. First, the scores of all independent variables (VFT quality factors) were centred. Then the cross-products of centred independent variables were created using VFT quality factors and the dummy variable, domestic or international student. Third, the moderating effects of domestic/international status were tested using hierarchical regressions. Table 4 summarizes the results of hierarchical regressions.

\section{***Please Insert Table 4 Here***}

Table 5 Table 4 shows that only model 2 was significant, which means domestic/international status moderated the relationship between Factor 2 content quality and students' overall satisfaction. The regression equation including moderating effect is:

Overall Satisfaction $=\mathrm{a}+\mathrm{b} 1 \mathrm{~F} 2+\mathrm{b} 2$ Domestic/International + b3 F2 * Status

Since domestic students were coded as 1 , the regression equation is:

Overall Satisfaction $=4.128+.222 \mathrm{~F} 2+.155(1)-.333 \mathrm{~F} 2(1)=4.283+.111 \mathrm{~F} 2$

Since international students were coded as 0 , the regression equation is:

Overall Satisfaction $=4.128+.222 \mathrm{~F} 2+.155(0)-.333 \mathrm{~F} 2(0)=4.128+.222 \mathrm{~F} 2$

The moderating effect of students' domestic/international status is also illustrated in Figure 1. The horizontal axis represents VFT content quality and the vertical axis represents overall satisfaction. The continuous line represents domestic students and the broken line represents international students. It is clear to see that the relationship between VFT content quality and overall satisfaction is stronger among a group of international students than among a group of domestic students.

\footnotetext{
***Please Insert Figure 1 Here***
} 


\section{Discussion of contributions}

\subsection{Theoretical contributions}

Virtual Field Trips (VFTs), as an important online learning tool, are gaining popularity in tertiary education, however, little research evidence has been obtained from courses and programs with strong practical vocational focus, such as hospitality management. It is interesting to see that our study has assisted in filling this gap as system quality aspect was considered the most important factor affecting students' overall satisfaction and support the findings of (Chako et al., 2005, Patiar et al., 2012). Even the enjoyment quality aspect had stronger impacts on satisfaction compared to content quality. For example, technical performance involving ease of access of learning material, ease of navigation, reasonable loading time and accomplishment of tasks effectively reduced students' anxiety involving researching and sourcing information to undertake and complete major assessments in the course. As several researchers point out, digital natives (students of today) desire fast results with minimal effort in terms of time and energy (Bennett, Maton \& Kervin, 2008; Jones \& Shao, 2011; Prensky, 2007). Furthermore, the use of technology in education encourages students' engagement with the course of study (Palfrey \& Gasser, 2008). While our results support some of the existing literature, at the same time we refute the findings of Devine, (2010), Kennedy et al., (2009) and Stanton and Stanton, (2013) that students use technology more for the leisure purposes than for the education purposes.

This does not mean that content quality aspect is not important but having easy access and ease of navigation, as well as being a fun system is the first and very important step to ensure a pleasant learning experience for students using the VFT tool (Chang \& Tung, 2007; Lin, 2007). In this type of action and authentic learning the individual is developed as is the wider system of stakeholder partnerships and collective decision making which supports the VFT innovation (Abbott \& Weiss, 2016). It also indicates from another perspective that there 
might still be room for improvement in terms of the technical and enjoyment aspects of the performance of this tool. If there is an increase in the quality of the system, then there will be an increase in student satisfaction with the VFT (Pawlowski, 2007). This can be extrapolated given the student coefficient of student satisfaction.

Additional interpretation reveals that domestic and international students differ in their satisfaction level, particularly for the dimension of content quality. In fact, the international students are more satisfied with content quality of the VFT, perhaps they lacked opportunities for practical work experience in the hospitality industry in Australia and in their home country. Moreover, general profile of students' shows that over $70 \%$ of the cohort are international students and over $80 \%$ of the cohort has had no work experience in the hospitality industry. This impression is also shared by other researcher in Australia, normally international students have difficulty in securing meaningful work related to their field of study due to various reasons, such as lack of local networks, poor understanding of the Australian labor market, the process of applying for the job, and weak oral communication skills (Blackmore et al., 2015). However, in the case of domestic (Australian) students it is customary to take part-time work in the hospitality industry as soon as they turn 16 and continue to work throughout their university life. Therefore, it is not surprising to note that those international and domestic students having no work experience are better fulfilled by VFT offering insights into the real workings of hotels' food and beverage operation.

The findings of the study verified the use of the VFT as an effective tool in orientating students with skills and knowledge of food and beverage management in hotels, before they gain traineeships or first employment positions and is consistent with other researchers’ findings (Govindasamy, 2002; Perez-Arostegui, et al., 2015). The VFT also provides access to practical aspects of food and beverage operations, which students might not be exposed to during work experience or part-time jobs. More importantly, the study developed 
measurements of the quality of the VFT tool, one of the first of this kind in the hospitality context. It further explored the underlying dimensions of the VFT and assessed the importance of each aspect in predicting students' satisfaction. This enriches existing theories on e-learning and expands and deepens the understanding of VFTs in hospitality education. The findings highlight the importance of system quality or the technical aspects of the tool in affecting students' learning experience and satisfaction, suggesting there is room for improvement in the future use of the VFT tool.

\subsection{Empirical contributions}

Having a practical component in the curriculum is a very important element for hospitality management education (Busby \& Gibson, 2010; Jenkins \& Walker, 1994). Constraints from the high cost involved with on-campus training facilities and offering mandatory work experience means the VFT tool might be an effective way of building students' knowledge foundation in the management of hotel food and beverage operations and their employability. While there is no substitute for physically being present in food and beverage operations, VFT experiences play a critical role in grooming students for their future careers in the hospitality business (Busby \& Gibson, 2010).

In fact, a VFT lets students search and then apply various aspects of food and beverage management practices drawn in the assessment brief. The results included the development of the students’ assessment task proposals for a concept restaurant, which impressively enhanced their understanding compared to prior efforts before the VFT was used as a learning tool. Moreover, students learning experiences with the VFT not only increased their knowledge but also played an important role in advancing their selfconfidence levels for developing appropriate business decisions. The effectiveness of the tool also provides empirical evidence for expanding the VFT tool in other courses (subjects) and 
programs of study. For example, the VFT tool can be easily transferred to other aspects of the hospitality and tourism businesses. VFTs have a valuable role in supporting and enhancing real fieldwork experiences and empowering students who are disadvantaged either financially or physically (Clark, 1996; Ford \& Hipple, 1998).

\section{Limitations and future research}

The study shows a positive relationship between VFT quality and students' satisfaction, and has enriched the literature in the field of technology enhanced learning. The study is limited by the use of convenient sampling and as a cross-sectional study. Longitudinal research looking at collective evidence across a number of semesters is highly desired for future research. How the VFT tool influences other aspects of students' learning experience as well as educators' experiences would also contribute to the development of technology to enhance learning literature. 


\section{References}

Abbott, C., \& Weiss, M. (2016). Doing different things or doing things different: Exploring the role of action learning in innovation. Action Learning: Research and Practice, 13(1), 41-49.

AEI (2012). Student Voices: Enhancing the Experience of International Students in Australia. Australian Government, Canberra.

Alexander, M. (2007). Reflecting on changes in operational training in UK hospitality management degree programs. International Journal of Contemporary Hospitality Management, 19(3), 211-220.

Arbaugh, J. (2014). Systems, scholar, or students? Which most influences online MBA course effectiveness? Journal of Computer Assisted Learning, 30(4), 349-362.

Australian Government (2015). Draft National Strategy for International Education, Australian Government, Canberra.

Baldwin, G. (2005). The teaching-research nexus: How research informs and enhances learning and teaching in the University of Melbourne. Melbourne: The University of Melbourne.

Bennett, S., Maton, K., \& Kervin, L. (2008). The digital natives’ debate: A critical review of the evidence. British Journal of Educational Technology, 39(5), 775-786.

Bennet, J. (2011). Work experience is what international students want. Campus Review, 29 August, available at:

http://www.campusreview.com.au/2011/08/work-experience-is-what-international-studentswant/

(accessed 16 November 2016).

Blackmore, J., Gribble, C., \& Raimi, M. (2015). International education, the formation of capital and graduate employment: Chinese accounting graduates' experiences of 
Australian labour market. Critical Studies in Education. doi: 10.1080/17508487.2015.1117505.

Bryant, J. L. (2006). Assessing expectations and perceptions of the campus experience: The Noel-Levitz Student Satisfaction Inventory, New Directions for Community Colleges, 2006: 25-35. doi: 10.1002/cc.234

Busby, G. D., \& Gibson, P. (2010). Tourism and hospitality internship experiences overseas: A British perspective. Journal of Hospitality, Leisure, Sport and Tourism Education, 9(1), 3-12.

Cerny, C.A., \& Kaiser, H.F. (1977). A study of a measure of sampling adequacy for factoranalytic correlation matrices. Multivariate Behavioral Research, 12(1), 43-47.

Chacko, H., Davidson, M., \& Green, Y. (2005). The "big easy or hard ask”: A case study of service quality in New Orleans hotels. Journal of Hospitality and Leisure Marketing, 13(3/4), 183-205.

Chang, S., \& Tung, F. (2008). An empirical investigation of students' behavioural intentions to use the online learning course websites. British Journal of Educational Technology, 39(1), 71-83.

Clark, R. (1996). Art Education: Issues in Postmodernist Pedagogy. National Art Education Association, Reston.

Claver, E., Tari, J., \& Pereira, J. (2006). Does quality impact on hotel performance. International Journal of Contemporary Hospitality Management, 18(4), 350-358.

Colbran, S., Gilding, A., Colbran, S., Oyson, M. J., \& Saeed, N. (2015). The impace of student-generated digital flashcards on student learning of constitutional law. The Law Teacher. doi: 10.1080/03069400.2015.1082239.

Craig-Smith, S., \& Ruhanen, L. (2006). Trends in Australia University Tourism Education: Three Decades of Growth and Development. In Papageorgiou, P. \& Svivas, E. (Eds.) 
Proceedings of Cutting Edge Research in Tourism-New Directions, Challenges and Applications. Guildford: University of Surrey.

Deming, W. (1985). Transformation of Western-style management. Interfaces, 15(3), 6-11. Devine, J. (2010). Five Myths and Realities About Generation Y. ECULTURE, 3(14), 136141. Retrieved 06 March 2015, from http://www.ro.ecu.edu.au

Durning, S.J, \& Artino, A.R. (2011). Situativity theory: A perspective on how participants and the environment can interact. AMEE Guide no. 52. Med Teach, 33(3), 188-199.

Dutton, C., \& Farbrother, C. (2005). Responding to Change in Higher Education Hospitality Provision: Two Universities’ Approaches, Link 12, HLSTN, The Higher Education Academy, York.

Elleven, R., Wircenski, M., Wircenski, J., \& Nimon, K. (2006). Curriculum-Based Virtual Field Trips: Career Development Opportunities for Students with Disabilities. The Journal for Vocational Special Needs Education, 28(3), 4-11.

Elliott, K.M., \& Shin, D. (2002). Student Satisfaction: an alternative approach to assessing this important concept. Journal of Higher Education Policy and Management, 24 (2), 199-209.

Ford, R. E., \& Hipple, J. D. (1998) GeoSystems today: an interactive casebook. Retrieved from http://www.wiley.com/college/ford test/index.html

Franks, P. C., \& Oliver, G. C. (2012). Experiential learning and international collaboration opportunities: Virtual Internships. Library Review, 61(4), 272-285.

Garvin, D. (1988). Managing Quality, Free Press: London

Glassner, A., \& Eran-Zoran, Y. (2016). Place-based learning: action learning in MA program for educational practitioners. Action Learning: Research and Practice, 13(1), 23-37.

Govindasamy, T. (2002). Successful implementation of e-learning pedagogical considerations. Internet and Higher Education, 4, 287-299. 
Gruber T., Fuß S., Voss R., \& Gláser-Zikuda, M. (2010). Examining student satisfaction with higher education services: Using a new measurement tool. The International Journal of Public Sector Management, 23, 105-123.

Gu, Q., Schweisfurth, M., \& Day. (2010). Learning and growing in a 'foreign' context: intercultural experiences of international students. Compare: A Journal of Comparative and International Education, 40(1), 7-23.

Hannafin, M., Hall, C., Land, S., \& Hill, J. (1994). Learning in Open-ended Environments: Assumptions, Methods, and Implications. Educational Technology, 34(8), 48-55.

Helgesen, Ø. (2006). Are loyal customers profitable? Customer satisfaction, customer (action) loyalty and customer profitability at the individual level. Journal of Marketing Management, 22(3), 245-266.

Helgesen, Ø., \& Nesset, E. (2007). What accounts for students' loyalty? Some field study evidence. International Journal of Educational Management, 21(2), 126 -143.

Herrington, J., \& Kervin, L. (2007). Authentic learning supported by technology: 10 suggestions and cases of integration in classrooms. Educational Media International, 44(3), 219-236.

Herrington, J., \& Herrington, A. (1998). Authentic assessment and multimedia: How university students respond to a model of authentic assessment. Higher Education Research and Development, 17(3), 305-322.

Herrington, J. \& Oliver, R. (2000). An instructional design framework for authentic learning environments. Educational Technology Research and Development, 48(3), 23-48.

Herrington, J., Reeves, T., Oliver, R., \& Woo, Y. (2002). Designing authentic activities for web-based courses. In Richards (Ed.). Proceedings of World Conference on ELearning in Corporate, Government, Healthcare, and Higher Education 2001, 18-27, Chesapeake, VA: AACE. 
Honey, M., Mandinach, E., \& McMillan, K. C. (2003). A retrospective on twenty years of education technology policy. Education Development Centre, Center for Children and Technology, U.S Department of Education, Office of Educational Technology.

Jenkins, A., \& Walker, L. (1994). Developing student capability through modular courses. London: Kogan Page.

Jones, C., \& Shao, B. (2011). The net generation and digital natives: implications for higher education. Higher Education Academy: York, UK.

Juran, J. (2001). Juran’s Quality Handbook, McGraw-Hill: New York.

Kember, D., \& Ginns, P. (2012). Evaluating teaching and learning: A practical handbook for colleges, universities and the scholarship of teaching. Abingdon, Oxfordshire: Routledge.

Kennedy, G., Dalgarno, B., Bennett, S., Gray, K., Waycott, J., Judd, T., Bishop, A., Maton, K., Krause, K., \& Chang, R. (2009). Educating the Net Generation: A Handbook of Findings for Practice and Policy. Australian Learning and Teaching Council. Retrieved 06 March 2015, from http://www.netgen.unimelb.edu.au/downloads/handbook/NetGenHandbookAll.pdf King, B., \& Craig-Smith, S. (2010). Tourism and Hospitality Education in Australia: Emerging Issues and Future Prospects. CAUTHE 2010: Tourism and Hospitality: Challenge the Limits. Hobart, Tas.: University of Tasmania.

Lee, I.-S. (2002). Gender differences in self-regulated on-line learning strategies within Korea’s University context. Educational Technology Research and Development, 50 (1), 101-109.

Lin, H. (2007). Measuring Online Learning Systems Success: Applying the Updated DeLone and McLean Model. Cyber Psychology and Behavior, 10(6), 817-820.

Lin, T., \& Chen, C. (2012). Validating the satisfaction and continuance intention 
of e-learning systems: Combining TAM and IS success models. International Journal of Distance Education Technologies, 10(1), 44-54. doi:10.4018/jdet.2012010103.

Lo, C. (2010). How student satisfaction factors affect perceived learning, Journal of the Scholarship of Teaching and Learning, 10(1), 47-54.

McPhee, P. (2014). The commonwealth used to Fund universities: what happened? The Conversation.From:http://theconversation.com/the-commonwealth-used-to-funduniversities-what-happened-27436 (accessed 16 November 2016).

Moore, G. C., \& Benbasat, I. (1991). Development of an instrument to measure the perceptions of adopting an information technology innovation. Information Systems Research, 2 (3), 173-191.

Morss, D. A. (1999). A study of student perspectives on Wed-based learning: WebCT in the classroom. Internet Research: Electronic Networking Applications and Policy, 9 (5), 393-408.

Oblinger, D. (2003). Boomers, gen-Xers, and millennials: understanding the 'new students'. EDUCAUSE Review, 38(4), 37-45.

O’Driscoll, F. (2012). What matters most: An exploratory multivariate study of satisfaction among first year hotel/hospitality management students. Quality Assurance in Education, 20(3), 237-258.

Oh, S., Ahn, J., \& Kim, B. (2003). Adoption of Broadband Internet in Kora: the Role of Experience in Building Attitude. Journal of Information Technology, 18 (4), 267280.

O’Neill, M., \& Palmer, A. (2004). Importance-performance analysis: a useful tool for directing continuous quality improvement in higher education. Quality Assurance in Education, 12 (1), 39-52. http://dx.doi.org/10.1108/09684880410517423

Palfrey, J., \& Gasser, U. (2008). Born digital: understanding the first generation of digital 
natives, Basic, New York.

Patiar, A., Davidson, M., \& Wang, Y. (2012). Competition, Total Quality Management Practices, and Performance: Evidence From Upscale Hotels. Tourism Analysis, 17(2), $195-211$.

Patiar, A., Ma, E., Kensbock, S., \& Cox, R. (2016). Hospitality Management Students’ Expectation and Perception of a Virtual Field Trip Website: An Australian Case Study using Importance-Performance Analysis. Journal of Hospitality \& Tourism Education, (Forthcoming).

Pawlowski, J. (2007). The quality adaptation model: Adaptation and adoption of the quality standards ISO/IEC 19796-1 for learning, education and training. Educational Technology \& Society, 10, 3-16.

Perez-Arostegui, M., Bustinza-Sanchez, F., \& Barrales-Molina, V. (2015). Exploring the relationship between information technology competence and quality management, Business Review Quarterly, 18(1), 4-17.

Phelan, K. V., \& Mills, J. (2010). An exploratory study of knowledge, skills, and abilities (KSAs) needed in undergraduate hospitality curricula in the convention industry. Journal of Human Resources Management in Hospitality and Tourism, 10(1), 96-116.

Phenix, P. (1963). Educational theory and inspiration. Educ Theory, 13(1), 1-64.

Prensky, M. (2007). From Digital Native to Digital Wisdom. Retrieved 4 June 2015, from http://marcprensky.com/writing/ Prensky-Intro_to_From_DN_to_DW.pdf

Rienties, B., Li, N., \& Marsh, V. (2015). Modeling and managing student satisfaction: use of student feed back to enhance learning experience. Subscriber Research Series 201516. Gloucester: Quality Assurance Agency.

Reeves, T. (2006). How do you know they are learning? The importance of 
alignment in higher education. International Journal of Learning Technology, 2(4), 3012-304.

Roca, J.C., Chiu, C.M., \& Martínez, F.J., (2006). Understanding e-learning continuance intention: An extension of the technology acceptance model. International Journal of Human-Computer Studies, 64(8), 683-696.

Ruby, A. (2009). International students: a $\$ 100$ billion business? 27 September, From: http://www.universityworldnews.com/article.php?story=20090925022811395\&query =International+students\%3A+a\%25100+billion+business (accessed 16 November 2016).

Sandars, J., Patel, R., Goh, P., Kokatailo, P., \& Lafferty, N. (2015). The importance of educational theories for facilitating learning when using technology in medical education. Medical Teacher, 37(11), 1039-1042. doi:10.3109/0142159X.2015.1019438

Shen, D., Cho, M-H., Tsai, C-L., \& Marra, R. (2013). Unpacking online learning experiences: Online learning self-efficacy and learning satisfaction. Internet and Higher Education, 19, 10-17.

Smith, W., Butcher, E., Litvin, S. W., \& Frash, R. (2015). Incorporating an Instructional Scaffolding Approach into the Classroom: Teaching for Authentic Learning in Hospitality and Tourism Education. Journal of Teaching in Travel and Tourism, 15, 264-277.

Snedecor, George W., \& Cochran, William G. (1989). Statistical Methods, Eighth Edition, Iowa State University Press.

Stanton, A., \& Stanton, W. (2013). Digital Natives Or Digital Neophytes: Business Student Perspectives On Course-Based Web 2.0 Applications. Academy of Educational Leadership Journal, 17(1), 119-137. 
Taylor, S., \& Todd, P. A. (1995). Understanding Information Technology Usage: A Test of Competing Models. Information Systems Research, 6(2), 144-176.

Tews, M., Stafford, K., \& Tracey, B. (2011). What matters most? The perceived importance of ability and personality for hiring decisions. Cornell Hospitality Quarterly, 53(2), 94-101.

Tigelaar, D., Dolmans, D., Wolfhagen, I., \& van Der Vleuten, C. (2004). The development and validation of a framework for teaching competencies in higher education. Higher Education, 48, 253-268.

Wang, J., Ayres, H., \& Huyton, J. (2009). Job Ready Graduates: A Tourism Industry Perspective. Journal of Hospitality and Tourism Management, 16(1), 62-72.

Winberg, T., \& Hedman, L. (2008). Student attitudes towards learning, level of preknowledge and instruction type in a computer-simulation: effects on flow experiences and perceived learning outcomes. Instructional Science, 36(4), 269-287.

Wong, G., Greenhalgh, T., \& Pawson R. (2010). Internet-based medical education: A realist review of what works, for whom and in what circumstances. BMC Med Educ 10(1), 12.

Zahra, A. (2012). Learning journals leading to authentic learning in a hospitality context. Journal of Teaching in Travel \& Tourism, 12(3), 277-294. 
Table 1

General Profile of Students $(n=182)$

\begin{tabular}{llll}
\hline Respondents' Profile & Frequency (\%) & Respondents' Profile & Frequency (\%) \\
\hline Gender & & Work Experience & \\
Male & $66(36.3)$ & No & $153(84.1)$ \\
Female & $116(63.7)$ & Yes & $29(15.9)$ \\
Age Group & & Plan after graduation & \\
$18-22$ & $100(54.9)$ & Undertake higher studies & $36(19.8)$ \\
$23-26$ & $71(39)$ & Join management traineeship & $86(47.3)$ \\
$27-30$ & $7(3.8)$ & Open my own business & $16(8.8)$ \\
$>30$ & $4(2.2)$ & Other & $43(23.6)$ \\
Nationality & & 5-Year Career Goal & \\
Domestic & $53(29.1)$ & Junior Management & $28(15.4)$ \\
International & $129(70.9)$ & Middle Management & $62(34.1)$ \\
Major & & Senior Management & $37(20.3)$ \\
Hotel Management & $74(40.7)$ & Manage my own Business & $38(20.9)$ \\
Int. Tour. Hotel Mgt. & $94(51.6)$ & Other & $17(9.3)$ \\
Other & $14(7.7)$ & & \\
\hline
\end{tabular}




\section{Table 2}

Factor Analysis Results of VFT Quality Features (n=182)

\begin{tabular}{|c|c|c|c|}
\hline \multirow{2}{*}{ Factors and Variables } & \multicolumn{3}{|c|}{ Varimax rotated loadings } \\
\hline & Factor 1 & Factor 2 & Factor 3 \\
\hline \multicolumn{4}{|l|}{ Factor 1 System Quality } \\
\hline The VFTW made learning materials easy to access. & .830 & & \\
\hline $\begin{array}{l}\text { The VFTW was easy to navigate to find the learning } \\
\text { materials. }\end{array}$ & .744 & & \\
\hline The waiting time for loading VFTW was reasonable. & .658 & & \\
\hline $\begin{array}{l}\text { The VFTW enabled me to accomplish course tasks } \\
\text { more effectively. }\end{array}$ & .701 & & \\
\hline \multicolumn{4}{|l|}{ Factor 2 Content Quality } \\
\hline $\begin{array}{l}\text { The learning material on the VFTW was displayed } \\
\text { appropriately. }\end{array}$ & & .599 & \\
\hline $\begin{array}{l}\text { The learning materials on the VFTW were up to date. } \\
\text { The VFTW provided me with a complete set of }\end{array}$ & & .767 & \\
\hline $\begin{array}{l}\text { learning } \\
\text { materials. }\end{array}$ & & .573 & \\
\hline $\begin{array}{l}\text { The learning material on VFTW was presented at level } \\
\text { that was easy to understand. }\end{array}$ & & .657 & \\
\hline The interface of the VFTW was user-friendly & & 740 & \\
\hline \multicolumn{4}{|l|}{ Factor 3 Enjoyment Quality } \\
\hline The use of multimedia (e.g. videos \& floor plan) & & & .822 \\
\hline \multicolumn{4}{|l|}{ attracts } \\
\hline The VFTW provided appropriate learning scenario(s). & & & .643 \\
\hline The use of VFTW added to my enjoyment of learning. & & & .745 \\
\hline \multicolumn{4}{|l|}{ General Information } \\
\hline Kaiser-Meyer-Olkin Measure of Sampling Adequacy & .916 & & \\
\hline Bartlett's Test of Sphericity & $=1070.055$ & $\mathrm{df}=66$ & Sig. $=.000$ \\
\hline$\%$ of variance explained & 60.404 & 7.649 & 5.378 \\
\hline Cronbanch's alpha & 0.852 & 0.853 & 0.891 \\
\hline Eigenvalue & 6.276 & 1.983 & 1.015 \\
\hline
\end{tabular}




\section{Table 3}

The Relationship Between VFT Dimensions and Students' Overall Satisfaction $(\mathrm{n}=182)$

\begin{tabular}{|c|c|c|c|c|}
\hline Dependent Variable & \multicolumn{4}{|c|}{ Overall Satisfaction } \\
\hline \multirow{3}{*}{ Independent Variables } & \multicolumn{4}{|c|}{ VFT Factor 1} \\
\hline & \multicolumn{4}{|c|}{ VFT Factor 2} \\
\hline & \multicolumn{4}{|c|}{ VFT Factor 3} \\
\hline Multiple R & \multicolumn{4}{|l|}{.567} \\
\hline $\mathrm{R}^{2}$ & \multicolumn{4}{|l|}{.322} \\
\hline Adjusted $\mathrm{R}^{2}$ & \multicolumn{4}{|l|}{.310} \\
\hline Standard Error & \multicolumn{4}{|l|}{699} \\
\hline Independent Variables & $\mathrm{B}$ & Beta & $\mathrm{t}$ & Sig. \\
\hline Constant & 4.059 & & 75.061 & $.000 *$ \\
\hline Factor 1 & .336 & .401 & 6.212 & $.000^{*}$ \\
\hline Factor 2 & .215 & .256 & 3.967 & $.000 *$ \\
\hline Factor 3 & .260 & .310 & 4.801 & $.000 *$ \\
\hline
\end{tabular}




\section{Table 4}

Hierarchical Regressions on the Moderating Effects of Domestic/International Status

\section{Model 1}

Dependent Variable Independent Variables

Change of $\mathrm{R}^{2}$

Significance of Change of $\mathrm{R}^{2}$
Overall Satisfaction

Centered F1 System Quality

Domestic/International

Domestic/International*Centered F1

.161

$.000^{*}$

\begin{tabular}{lllll}
\hline Independent Variables & $\mathrm{B}$ & $\mathrm{Beta}$ & $\mathrm{t}$ & Sig. \\
Constant & 4.053 & & 67.869 & $.000^{*}$ \\
Centered F1 & .359 & .428 & 5.619 & $.000^{*}$ \\
Domestic/International & -.052 & -.041 & -.422 & .674 \\
Domestic/International*Centered F1 & -.124 & -.014 & -.186 & .853 \\
\hline
\end{tabular}

Dependent Variable

Independent Variables

Change of $\mathrm{R}^{2}$

Significance of Change of $\mathrm{R}^{2}$
Model 2

Overall Satisfaction

Centered F2 Content Quality

Domestic/International*Centered F2

.082

$.001^{*}$

\begin{tabular}{lllll}
\hline Independent Variables & $\mathrm{B}$ & $\mathrm{Beta}$ & $\mathrm{t}$ & \multicolumn{2}{c}{ Sig. } \\
Constant & 4.128 & & 55.498 & $.000^{*}$ \\
Centered F2 & .222 & .265 & 3.535 & $.000^{*}$ \\
Domestic/International & .155 & -.128 & -1.711 & .089 \\
Domestic/International*Centered F2 & -.333 & -.249 & -2.630 & $.009^{*}$ \\
\hline
\end{tabular}

Model 3

Dependent Variable Independent Variables

Change of $\mathrm{R}^{2}$

Significance of Change of $\mathrm{R}^{2}$
Overall Satisfaction

Centered F3 Enjoyment Quality

Domestic/International

Domestic/International*Centered F3

.103

.000

\begin{tabular}{lllll}
\hline Independent Variables & $\mathrm{B}$ & $\mathrm{B}$ & $\mathrm{t}$ & \multicolumn{2}{c}{ Sig } \\
Constant & 4.105 & & 55.832 & $.000^{* *}$ \\
Centered F2 & .254 & .303 & 4.087 & $.000^{*}$ \\
Culture & -.155 & -.083 & -1.124 & .263 \\
Culture*Centered F2 & -.235 & -.161 & -1.788 & .076 \\
\hline
\end{tabular}




\section{Overall Satisfaction}

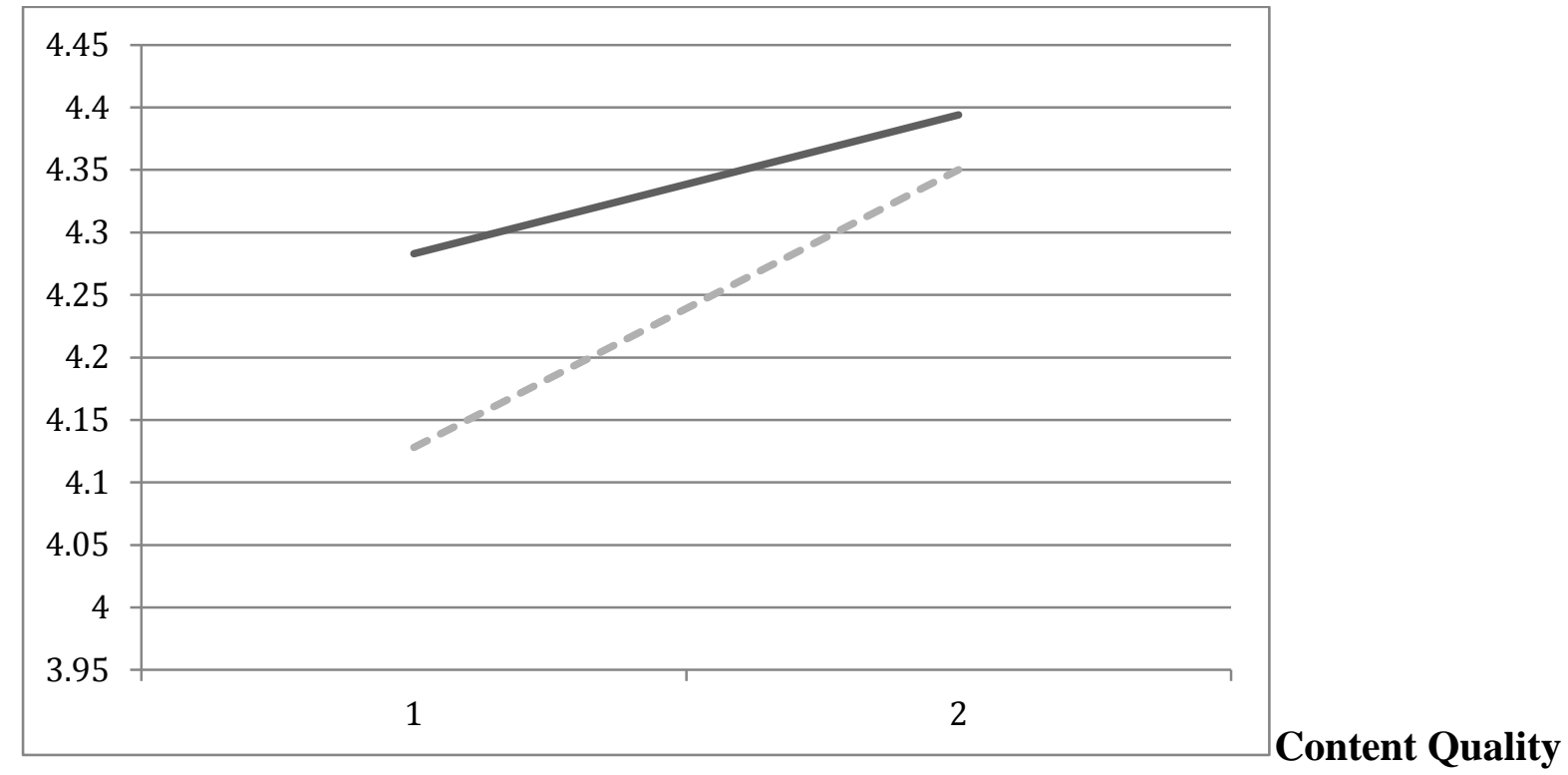

Figure 1. Moderating effects of Domestic/International Status

Dependent Variable: Overall Satisfaction; Independent Variable: Content Quality Continuous line: Domestic Students; Broken line: International Students 